\title{
KINETICS OF ANTIGEN SPECIFIC AND NON-SPECIFIC POLYCLONAL B-CELL RESPONSES DURING LETHAL PLASMODIUM YOEL// MALARIA
}

\author{
LAURENCE ROLLAND; JEAN JACQUES BALLET* \& \\ CLAUDIO DANIEL-RIBEIRO** ${ }^{+}$
}

\begin{abstract}
INSERM U 313, Groupe Hospitalier Pitié-Salpétriere, 75643 Paris cédex 13, France *INSERM U 108 , Hôpital St-Loujs, 75475 Paris cédex 10, France **Departamento de Imunologia, Instituto Oswaldo Cruz, Av. Brasil 4365, 21045-900 Rio de Janeiro, RJ, Brasil
\end{abstract}

In order to study the kinetics and composition of the polyclonal B-cell activation associated to malaria infection, antigen-specific and non-specific B-cell responses were evaluated in the spleens of mice infected with Plasmodium yoelii $17 X \mathrm{~L}$ or injected with lysed erythrocytes or plasma from $\mathrm{P}$. yoelii infected mice or with $\mathrm{P}$. falciparum culture supernatants. Spleen/body weight ratio, numbers of nucleated spleen cells and Immunoglobulin-containing and Immunoglobulin-secreting cells increased progressively during the course of infection, in parallel to the parasitaemia. A different pattern of kinetics was observed when anti-sheep red blood cell and anti-trinitrophenylated-sheep red blood cell plaque forming cells response were studied: maximum values were observed at early stages of infection, whereas the number of total Immunoglobulin-containing and Immunoglobulin-secreting cells were not yet altered. Conversely, at the end of infection, when these latter values reached their maximum, the anti-sheep red blood cell and anti-trinitrophenylated-sheep red blood cell specific responses were normal or even infranormal. In mice injected with Plasmodium-derived material, a higher increase in antigenspecific PFC was observed, as compared to the increase of Immunoglobulin-containing and Immunoglobulin-secreting cell numbers. This suggested a "preferential" (antigen-plus mitogeninduced) stimulation of antigen-specific cells rather than a generalized non-specific (mitogeninduced) triggering of B-lymphocytes. On the basis of these and previous results, it is suggested that the polyclonal $B$-cell activation that takes place during the course of infection appears as a result of successive waves of antigen-specific B-cell activation.

Key words: polyclonal B-cell activation - malaria - Plasmodium yoelii - plaque forming cells * antigen

The existence of a polyclonal B-cell activation, induced by parasite-derived mitogen during malaria infection was first suggested by Greenwood (1974) on the basis of the diversity of immune response observed in human infected patients (Greenwood et al., 1971; Houba et al., 1974), confirmed also in our previous work (Daniel-Ribeiro et al., 1983). Further evidence for this hypothesis came with the observation by Freeman \& Parish (1978) that the number of plaque forming cells (PFC) specific for either sheep or horse red blood cells (SRBC and HRBC) were elevated in the spleens of $\mathrm{Balb} / \mathrm{c}$ mice in the early stages of

\footnotetext{
Research supported by grants from "Fondation pour la Recherche Médicale, France" and "Conselho Nacional de Desenvolvimento Cientifico e Tecnológico $(\mathrm{CNPq})$, Brasil" to Dr Claudio Daniel-Ribeiro.

${ }^{+}$Corresponding author.

Received 11 September 1991. Accepted 20 March 1992.
}

Plasmodium yoelii $(17 \mathrm{XL})$ and $P$. berghei (K173) experimental infection. Similar results were found by Rosenberg (1978), who draw attention to the fact that, while the number of some specific (anti-SRBC and anti-bromelain treated mouse RBC) PFC transiently increased at the 4th day of infection, that of the total immunoglobulin secreting cell (Ig-S) and curiously that of anti-trinitrophenyl-SRBC (TNPSRBC) PFC, rose steadily until day 7 , the usual time of death of $P$. berghei infected $\mathrm{Balb} / \mathrm{c}$ mice. However, this short survival of the animals did not allow to exclude the possibility that the kinetics of anti-TNP and/or even the total Ig response could be in fact similar to those against SRBC and bromelain treated mouse RBC (brMRBC), but with latter peaks.

In addition, although the increase in the number of PFC specific for heterologous erythrocytes has been previously considered as evidence of polyclonal B-cell activation (Fauci \& 
Pratt, 1976; Freeman \& Parish, 1978; Corsini \& Costa, 1981), this does not exclude that these cells are indeed activated by specific mechanisms (involving cross-reactions between parasites or modified autologous antigens and the heterologous target erythrocytes) rather than by a polyclonal activation phenomenon. In order to study the participation of antigen-specific B-cell responses in the polyclonal B-cell activation associated to malaria infection, we developed a model of $P$. yoelii $17 \mathrm{XL}$ experimental rodent malaria using a low number $\left(10^{4}\right)$ of infected RBC and a more resistant strain of mice $(\mathrm{CBA} / \mathrm{J})$. This extended the course of infection for two to three weeks and survival of infected animals permitted the appreciation of the kinetics and composition of the polyclonal B-cell activation in malaria.

Besides this, in order to investigate the role of Plasmodium-derived substances in malariaassociated polyclonal activation, the parameters examined in infected mice were comparatively examined in animals injected with non-infectious plasmodial extracts.

\section{MATERIALS AND METHODS}

Parasite and infection - A lethal variant (17XL) of the $P$. yoelii $(17 \mathrm{X})$ strain (a kind gift from Prof. J. H. L. Playfair, Middlesex Hospital Medical School, London - Playfair et al., 1977) was used in all experiments. This strain was maintained by serial intraperitoneal (ip) inoculation of parasitized red blood cells (RBC) to mice. Four to five week old CBA/J or Swiss CD1 mice (CSEAL, Orleans, France) were infected by the ip inoculation with $10^{4}$ RBC from $P$. yoelii $17 \mathrm{XL}$ infected syngenic mice. Parasitaemia was determined by examination of Giemsa-stained thin blood smears. With this infecting dose most of the CBA/J mice had a long lasting infection, with a maximum parasitaemia $(70 \%)$ reached by day 18 , self-cured around day 21. Infection of Swiss CD1 mice was invariably fatal, the mean survival time being about 15 days.

Parasite-derived material and injection Infection of 11 week old female Swiss CD1 mice was initiated by ip inoculation of $10^{4} P$. yoelii $17 \mathrm{XL}$ parasitized erythrocytes. Ten days later, when the parasitaemia reached an average of $45 \%$, blood was collected on heparin, centrifuged $(800 \mathrm{~g}, 10 \mathrm{~min})$ and pooled plasma were separated and filtered $(0.22 \mu \mathrm{m})$. After removing the buffy coat of the white cells, pooled erythrocytes were washed in sterile
$0.9 \% \mathrm{NaCl}$ solution $(800 \mathrm{~g}, 10 \mathrm{~min})$ and lysed at $4{ }^{\circ} \mathrm{C}$ by addition of three volumes of sterile distilled water. Hemolysates were centrifuged $(30000 \mathrm{~g}, 30 \mathrm{~min})$ and the supernatant filtered $(0.22 \mu \mathrm{m})$. Filtered $(0.22 \mu \mathrm{m}) P$. falciparum (UPA) supernatants were obtained from in vitro long term culture containing $10 \%$ parasitized human erythrocytes, as previously described (Druilhe et al., 1980). Control hemolysates, plasma and supernatants were prepared from non-infected material using the same procedures. All parasite-derived and the control preparations were stored at $-20^{\circ} \mathrm{C}$, until required. Six week old female $\mathrm{CBA} / \mathrm{J}$ mice were injected ip with $0.5 \mathrm{ml}$ of either plasmodial or control extracts.

Direct immunofluorescence antibody test Ig-containing (Ig-C) cells were detected by a direct immunofluorescence test performed on smears of spleens cells (Cooper et al., 1971). Dried smears were fixed in absolute ethanol for $10 \mathrm{~min}$ and rehydrated in $10 \mathrm{mM}$ phosphate-buffered saline (PBS). They were then incubated for $30 \mathrm{~min}$ at $20^{\circ} \mathrm{C}$ in dark with a $1 / 500$ fluorescein-labelled goat anti-Ig mouse (Fab)' 2 specific antibody (Nordic, Thilburg, The Netherlands). After three washings in PBS, slides were covered with PBS-glycerol $(\mathrm{V} / \mathrm{V})$.

Plaque forming cell assays - Plaque forming cells were detected using a modified double slide liquid assay, as previously described (Cunningham \& Szenberg, 1968; Dresser, 1978). Specific PFC against SRBC and TNPSRBC were evaluated using unmodified SRBC or TNP coupled SRBC as indicator cells; TNPSRBC were prepared according to Rittenberg \& Pratt (1969). Total Ig-S cells were assessed by a reverse PFC assay (Dresser, 1978), using sheep anti-mouse Ig-coupled SRBC, via a chromic chloride-mediated coupling of Staphylococcus aureus protein A (Pharmacia, Upsala, Sweden), as target cells (Gronowicz et al., 1976) and a rabbit anti-mouse Ig-antiserum as developer. In each assay, fresh guinea pig serum, previously absorbed with the appropriated target cells (incubation at $4{ }^{\circ} \mathrm{C}$ for 30 min, two times) was the source of complement. Each PFC assay was performed in duplicate.

Statistical evaluation of data - The Student's $t$ test was used as criterion for variance analysis in experimental and control data, thus assuming a near normal distribution of values. 
TABLE 1

Spleen parameters in Plasmodium yoelii (17XL) infected mice

\begin{tabular}{|c|c|c|c|c|c|c|c|c|c|}
\hline Mice & Day & Parasitaemia $^{a}$ & $\begin{array}{c}\text { Relative } \\
\text { spleen weight } b \\
\text { (g) }\end{array}$ & $\begin{array}{l}\text { Nucleated } \\
\text { spleen cells }{ }^{c}\end{array}$ & $\mathrm{Ig}-\mathrm{C}^{d}$ & $\lg \cdot \mathrm{S}^{e d}$ & $\frac{\operatorname{Ig}-\mathrm{C}}{\lg -\mathrm{S}}$ & SRBC-PFC $f$ & TNP-PFC $g$ \\
\hline CBA/J & $\begin{array}{r}0 \\
4 \\
6 \\
18\end{array}$ & $\begin{array}{c}- \\
1.5 \pm 0.5 \\
11.4 \pm 1.5 \\
50.0 \pm 3.0\end{array}$ & $\begin{array}{r}3.7 \pm 0.7 \\
5.0 \pm 1.0 \\
10.8 \pm 2.0 \\
55.3 \pm 7.2\end{array}$ & $\begin{array}{r}6.3 \pm 1.5 \\
7.1 \pm 1.7 \\
17.5 \pm 2.9 \\
97.3 \pm 20.6\end{array}$ & $\begin{array}{r}0.9 \pm 0.10 \\
1.9 \pm 0.05 \\
4.6 \pm 0.90 \\
14.7 \pm 2.50\end{array}$ & $\begin{array}{r}1.5 \pm 1.1 \\
1.2 \pm 0.4 \\
6.3 \pm 0.5 \\
159.0 \pm 10.0\end{array}$ & $\begin{array}{r}6.0 \\
15.8 \\
7.3 \\
0.9\end{array}$ & $\begin{array}{r}135.0 \pm 72.0 \\
883.0 \pm 12.0 \\
525.0 \pm 0.2 \\
13.5 \pm 0.6\end{array}$ & $\begin{array}{l}\text { ND } \\
\text { ND } \\
\text { ND } \\
\text { ND }\end{array}$ \\
\hline $\begin{array}{l}\text { SWISS } \\
\text { (CD1) }\end{array}$ & $\begin{array}{r}0 \\
4 \\
9 \\
11\end{array}$ & $\begin{array}{c}- \\
0.9 \pm 0.6 \\
49.0 \pm 3.0 \\
69.0 \pm 8.2\end{array}$ & $\begin{array}{r}6.3 \pm 1.3 \\
7.4 \pm 2.7 \\
16.8 \pm 2.6 \\
34.6 \pm 3.2\end{array}$ & $\begin{array}{l}15.6 \pm 1.9 \\
21.4 \pm 8.8 \\
36.7 \pm 2.5 \\
84.3 \pm 5.3\end{array}$ & $\begin{array}{l}\text { ND } \\
\text { ND } \\
\text { ND } \\
\text { ND }\end{array}$ & $\begin{array}{r}2.7 \pm 1.2 \\
1.3 \pm 0.2 \\
3.8 \pm 0.4 \\
18.7 \pm 0.2\end{array}$ & $\begin{array}{l}- \\
- \\
- \\
-\end{array}$ & $\begin{array}{r}21.1 \pm 15.30 \\
626.0 \pm 36.30 \\
6.6 \pm 1.90 \\
1.8 \pm 0.85\end{array}$ & $\begin{array}{r}1.8 \pm 0.7 \\
2.5 \pm 1.2 \\
13.0 \pm 0.3 \\
1.1 \pm 0.5\end{array}$ \\
\hline
\end{tabular}

a: percentage of parasitized red blood cells in circulating blood; $b: 1_{10^{-3}} \mathrm{~g} ; c: \times 10^{7} ; d:$ immunoglobulin containing (Ig-C) or secreting (lg-S) cells per 100 nucleated spleen cells: $e: \times 10^{-1} ; f:$ per $10^{8}$ nucleated spleen cells; $g$ : per $10^{s}$ nucleated spleen cells; $\mathrm{ND}=$ not done.

\section{RESULTS}

Effects of $\mathrm{P}$. yoelii infection and Plasmodium-derived material on the relative spleen weight and on the number of nucleated spleen cells - In both CBA/J and Swiss CD1 infected mice, the spleen/total body weight ratio as well as the number of nucleated cells were unaltered until day 4 (Table I, Figs 1a, b). In CBA/ $\mathrm{J}$ infected mice the values were higher, they were significantly increased at day 6 (two to three times the normal) and increased simultaneously with the parasitaemia, reaching values as high as 15 times the normal at day 18 .

None of the $\mathrm{CBA} / \mathrm{J}$ mice injected with plasmodial plasma or hemolysates became infected, as assessed by weekly microscopic examination of Giemsa-stained blood thin films. Injection of plasmodial hemolysates, plasma or culture supernatants (but not of control preparations) was followed by a limited and transient, although significant increase $(\mathrm{p}<0.001, \mathrm{p}<0.001$ and $\mathrm{p}<0.01$, respectively), in the spleen/total body weight ratio (Table II). A mild increase in the number of nucleated cells was temporarily observed following the injection of plasmodial plasma or hemolysates $(\mathrm{p}<0.001)$. It is noteworthy that, although significant, these effects were minimal when compared to the 15 fold increase in both parameters observed in $P$. yoelii $17 \mathrm{XL}$ infected mice. The effect of culture supernatant was not significant $(\mathrm{p}>0.05)$.

Effects of $\mathrm{P}$. yoelii infection and injection of Plasmodium-derived material on the numbers of Ig-C and Ig-S plasma cells - Ig production and secretion were studied at the single cell level. At day 2 of infection, the percentage of Ig-C was already twice the normal value. A continuous increase in these values was then noted, reaching a 16 fold increase at day 18 (Table I). Fig. 2 shows representative results obtained with $\mathrm{CBA} / \mathrm{J}$ mice. The cellular differentiation was more striking if one considers simultaneously the total spleen cell number: at day 18 , the total number of Ig-C was 250 fold higher than the normal values. 'The kinetics of generation of Ig-S in CBA/J (Fig. 3) and Swiss CD1 mice (Fig. 4) were similar to that of IgC. In order to assess the respective relevance of differentiation and stimulation of B-lymphocytes, we calculated the $\mathrm{Ig}-\mathrm{C} / \mathrm{Ig}-\mathrm{S}$ ratio in $\mathrm{CBA} / \mathrm{J}$ infected mice. In normal animals, this ratio was around 6 . On the 4th day of infection, it rose to 15.8 showing that the predominant phenomenon at this stage of infection was B-cell differentiation. Conversely, at day 18 , this ratio fell to 1 , illustrating the relevance of B-cell stimulation in the late stages of infection.

Injection of hemolysates from $P$. yoelii infected RBC, plasma from $P$. yoelii infected mice and supernatants from in vitro $P$. falciparum cultures generated respectively a $2.2(\mathrm{p}<0.001), 2.9(\mathrm{p}<0.02)$ and $1.7(\mathrm{p}<$ 0.01 ) fold increases in the percentage of Ig-C with peaks at days 4, 4 and 6 respectively (Table II). Once more, effects of these noninfectious stimulants were temporary and limited, as compared to the 16 fold increase noted at day 18 in infected mice (Table I, Fig. 2).

In the same way, plasma or hemolysatc injected mice presented a kinetics of generation of Ig-S similar to that of Ig-C: slight in- 

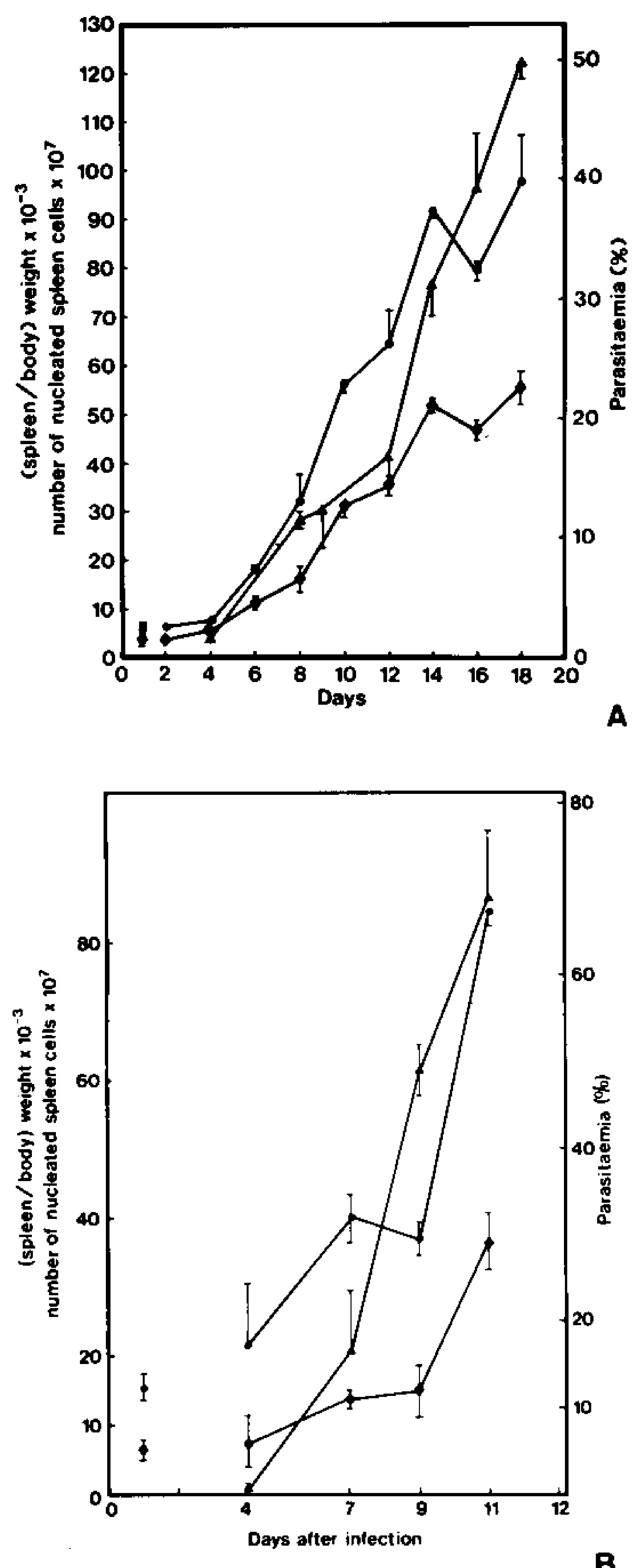

Fig. 1: parasitaemia $(\boldsymbol{\Delta})$, spleen/body weight $(\bullet)$, and total nucleated spleen cells $(\boldsymbol{O})$ in Plasmodium yoelii (17XL) infected CBA/J (A) and Swiss CDl (B) mice. Day 0 values represent the mean \pm SD obtained from 18 CBA/J or 12 Swiss CD1 non-infected control mice.

For the other days, each point represents the mean \pm $1 \mathrm{SD}$ from at least 4 animals.

creases were observed $-2.5(p<0.001)$ and $3.1(\mathrm{p}<0.01)$, respectively (Table II). This contrasted with the 100 fold increase observed in $P$. yoelii infected mice. No influence of culture supernatants or control preparations was detected (Table II).

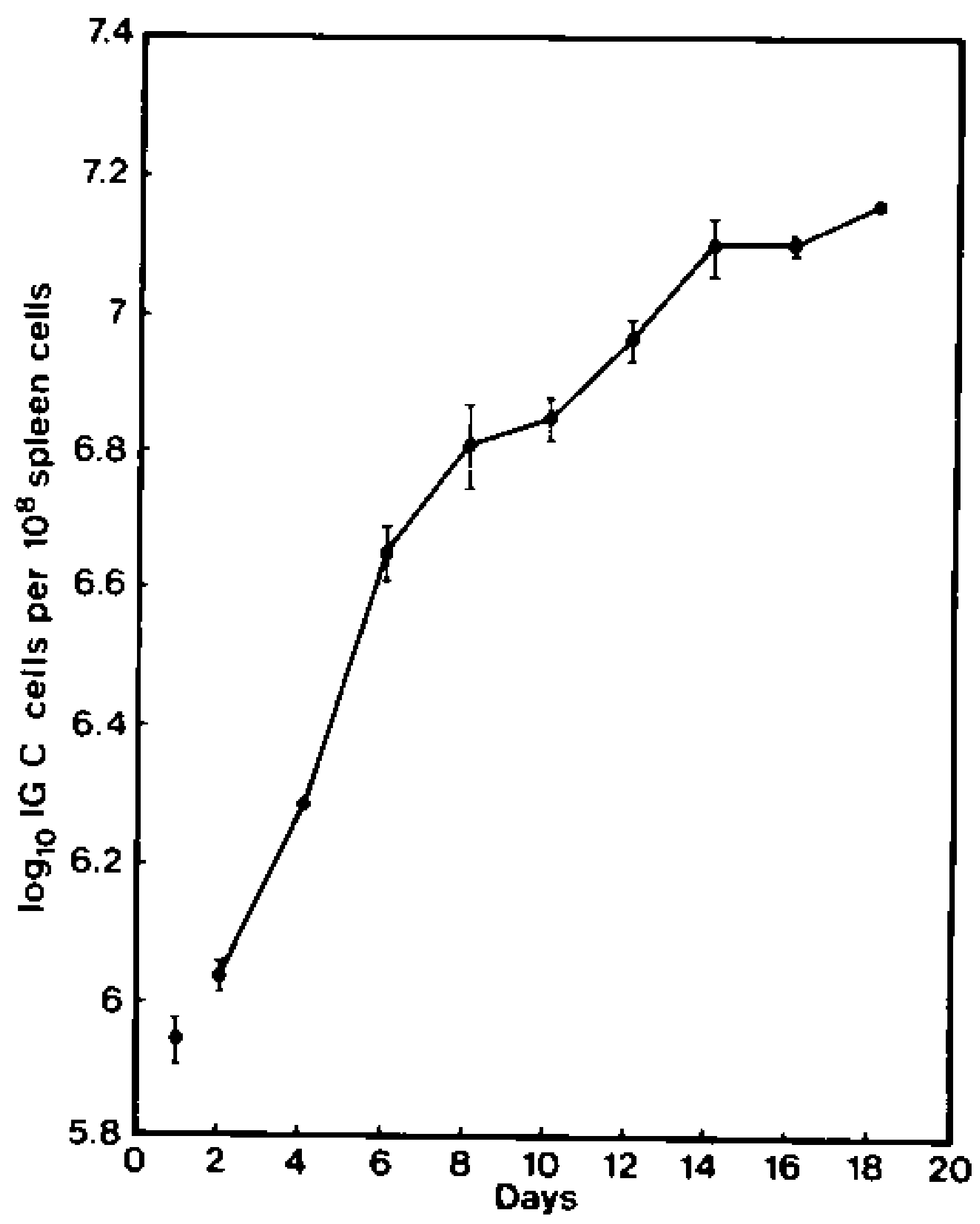

Fjg. 2: immunoglobulin-containing cells (lg-C) per $10^{8}$ nucleated spleen cells in Plasmodium yoelii (17XL) infected $\mathrm{CBA} / \mathrm{J}$ mice. For the number of animals in each point, see legend of Fig. 1.

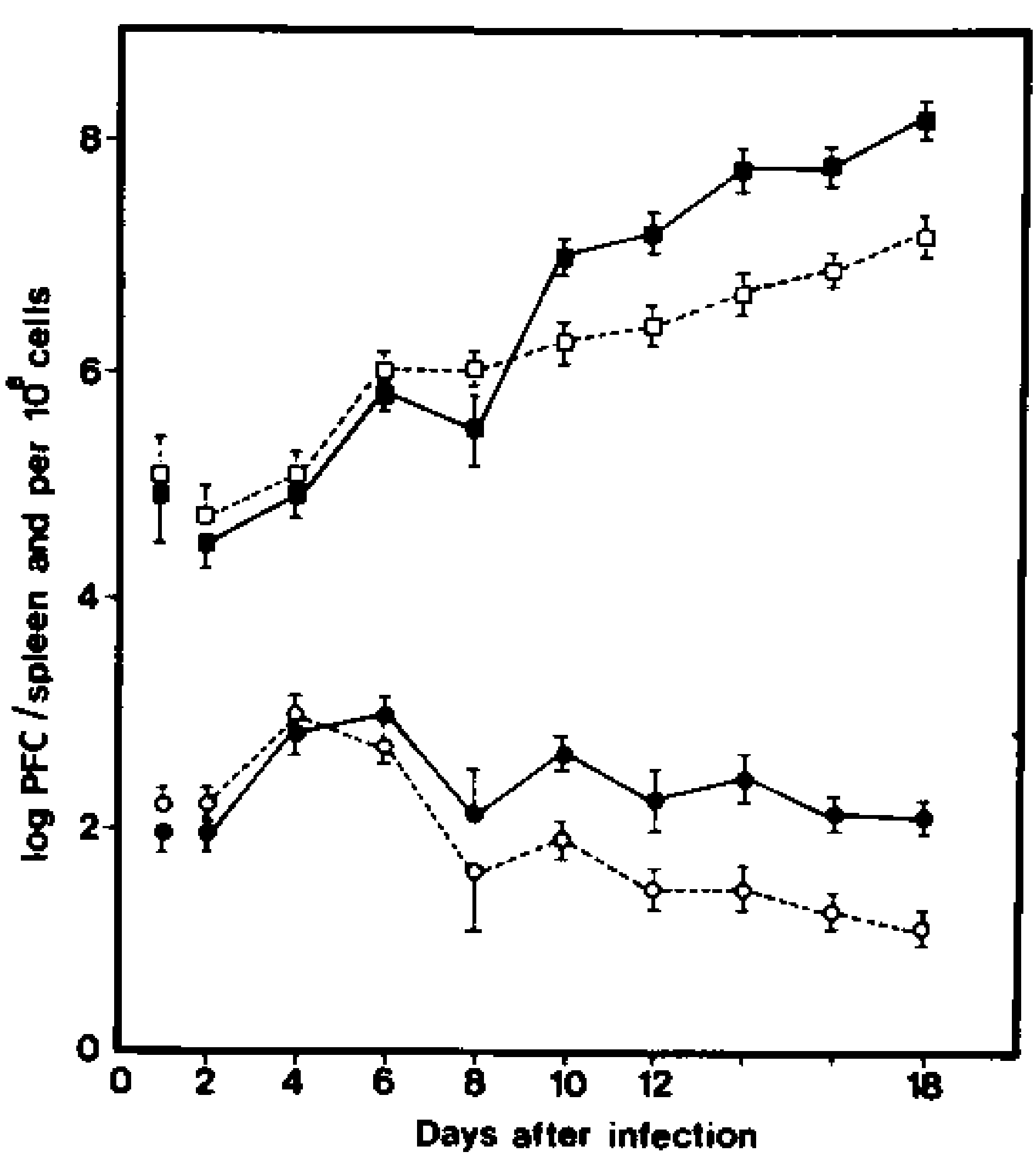

Fig. 3: total Ig PFC $(\square, \square)$ and anti-SRBC PFC $(\bullet, 0)$ in the spleen of Plasmodium yoelii (17XL) infected $\mathrm{CBA} / \mathrm{J}$ mice. Numbers are expressed per spleen $(-)$ and per $10^{8}$ nucleated cells $(----$ ). For number of animals tested at each point, see legend of Fig. 1. 
TABLE II

Spleen parameters in CBA/J mice injected with Plasmodium - derived material

\begin{tabular}{|c|c|c|c|c|c|c|c|}
\hline Treatment & $\begin{array}{l}\text { Relative } \\
\text { spleen weight } \\
\text { (g) }\end{array}$ & $\underset{\text { spleen cells }}{\text { Nucleated }}$ & $\mathrm{Ig}-\mathrm{C}^{c}$ & $\mathrm{Ig}-\mathrm{S}^{c d}$ & $\frac{\mathrm{Ig}-\mathrm{C}}{\mathrm{Ig}-\mathrm{S}}$ & $\begin{array}{l}\text { SRBC } \\
\text { PFC }^{e}\end{array}$ & $\begin{array}{l}\text { TNP } \\
\text { PFC }^{f}\end{array}$ \\
\hline $\begin{array}{l}\text { None } \\
\text { Normal Plasma } \\
\text { Malaria Plasma }\end{array}$ & $\begin{array}{l}5.0 \pm 0.90 \\
4.2 \pm 0.15 \\
8.0 \pm 0.30\end{array}$ & $\begin{array}{r}11.0 \pm 1.4 \\
8.8 \pm 1.5 \\
15.4 \pm 1.3\end{array}$ & $\begin{array}{l}1.0 \pm 0.07 \\
1.0 \pm 0.01 \\
2.9 \pm 1.10\end{array}$ & $\begin{array}{l}1.4 \pm 0.80 \\
1.8 \pm 0.30 \\
4.3 \pm 0.40\end{array}$ & $\begin{array}{l}7.1 \\
5.5 \\
6.7\end{array}$ & $\begin{array}{r}50 \pm 25 \\
460 \pm 80 \\
1660 \pm 120\end{array}$ & $\begin{array}{l}\text { ND } \\
\text { ND } \\
\text { ND }\end{array}$ \\
\hline $\begin{array}{l}\text { None } \\
\text { Normal Hemolysate } \\
\text { Malaria Hemolysate }\end{array}$ & $\begin{array}{l}3.5 \pm 0.50^{g} \\
5.0 \pm 1.40 \\
7.2 \pm 0.20\end{array}$ & $\begin{array}{c}6.8 \pm 1.5^{g} \\
9.3 \pm 2.5 \\
15.3 \pm 0.5\end{array}$ & $\begin{array}{l}1.1 \pm 0.30 \\
1.0 \pm 0.05 \\
2.4 \pm 0.15\end{array}$ & $\begin{array}{l}0.6 \pm 0.20 \\
0.7 \pm 0.40 \\
1.5 \pm 0.40\end{array}$ & $\begin{array}{l}18.3 \\
14.3 \\
16.0\end{array}$ & $\begin{array}{l}100 \pm 50 \\
168 \pm 30 \\
500 \pm 50\end{array}$ & $\begin{array}{l}2.30 \pm 0.70 \\
2.90 \pm 0.25 \\
4.25 \pm 1.30\end{array}$ \\
\hline $\begin{array}{l}\text { None } \\
\text { Normal supernatant } \\
\text { Malaria supernatant }\end{array}$ & $\begin{array}{l}3.5 \pm 0.50^{h} \\
3.9 \pm 0.10 \\
5.3 \pm 0.20\end{array}$ & $\begin{array}{r}6.8 \pm 1.5^{h} \\
8.3 \pm 0.1 \\
12.2 \pm 2.2\end{array}$ & $\begin{array}{l}1.1 \pm 0.30 g \\
0.7 \pm 0.10 \\
1.9 \pm 0.40\end{array}$ & $\begin{array}{l}0.6 \pm 0.20^{g} \\
0.7 \pm 0.20 \\
0.8 \pm 0.09\end{array}$ & $\begin{array}{l}18.3 \\
10.0 \\
23.7\end{array}$ & $\begin{array}{lr}100 \pm & 50 \\
130 \pm & 6 \\
210 \pm & 8\end{array}$ & $\begin{array}{l}2.30 \pm 0.70 \\
2.00 \pm 0.09 \\
2.90 \pm 0.85\end{array}$ \\
\hline
\end{tabular}

$a: \times 10^{3} ; b: \times 10^{7} ; c$ : immunoglobulin containing ( $\mathrm{lg}-\mathrm{C}$ ) or secreting $(\mathrm{Ig}-\mathrm{S})$ cells per 100 nucleated spleen cells; $;: \times 10^{-1} ; e:$ per $10^{8}$ nucleated spleen cells; $f:$ per $10^{5}$ nucleated spleen cells. Data represent values observed at the peak of the response and, unless otherwise specified, concern day $4: g$ : day $6 ; h$ : day 9 .



Fig. 4: total $\operatorname{Ig} \operatorname{PFC}(\square, \square)$ and anti-TNP-SRBC $(\Delta, \triangle)$ and anti-SRBC PFC $(\bullet, O)$ in the spleen of Plasmodium yoelii (17XL) infected Swiss CD1 mice. Numbers are expressed per spleen (- $\longrightarrow$ and per $10^{8}$ nucleated cells $(----)$. For number of animals tested at each point, see legend of Fig. 1.

Effects of $P$. yoelii infection and injection of Plasmodium-derived material on the numbers of anti-SRBC and anti-TNP-SRBC PFC $P$. yoelii infection in $\mathrm{CBA} / \mathrm{J}$ (Fig. 3) and Swiss CD1 mice (Fig. 4) was associated with similar increase in the number of anti-SRBC PFC. This number, expressed per $10^{8}$ nucleated spleen cells, reached maximum values (6.5 and 30 fold, respectively) on the 4th day of infection, when the polyclonal B-cell activation, as detected by total Ig PFC, was yet unapparent. Values were then back to preinfection ones, and decreased afterwards. For anti-TNP-SRBC $\mathrm{PFC}$ response, representative results in Swiss CD1 infected mice are illustrated in Fig. 1. In this case, values started to rise at day 4 (1.4 fold) and reached the peak response ( 7.2 fold) at day 9 . Once more, in the later stages of the infection, whereas the polyclonal B-cell activation was maximal, these antigen-specific PFC numbers were below normal values.

As shown in Table 11 , injection of mice with hemolysates or plasma, prepared from $P$. yoelii infected mice, resulted in a 5 to 33 fold increase in the background of anti-SRBC PFC, despite their restricted B-cell activating properties as reflected by the limited effects ( 2 to 3 fold) on the total Ig-C and Ig-S numbers. It must be pointed out that mice injected with control plasma also showed a significant ( 9 fold) increase in the number of anti-SRBC PFC. The effect of $P$. falciparum culture supernatants was not significant $(\mathrm{p}>0.2)$. The less marked increase (1.95 fold) observed in the number of anti-TNP-SRBC PFC in mice injected with plasmodial hemolysate, was not significant $(\mathrm{p}>0.05)$.

\section{DISCUSSION}

The experimental model of malaria infection used in this study (low inoculum of $10^{4}$ of P. yoelii $17 \mathrm{XL}$ and $\mathrm{CBA} / \mathrm{J}$ resistant mice strain) 
permitted us to confirm and extend previous reports demonstrating the existence of a polyclonal B-cell activation phenomenon in rodent malaria (Rosenberg, 1978, 1981; Weinbaum et al., 1978; Langhorne et al., 1985; Falanga et al., 1987; Mori et al., 1987) and in human malaria (Daniel-Ribeiro et al., 1986; Banic et al., 1991).

As reported here, $P$. yoelii infected mice prescnted a pronounced splenomegaly with a marked cell number increase, parallel to the parasitaemia. Simultaneously, a cell differentiation, that represented a major event in early stage of infection, was recorded. At the later stages of the course of infection, despite the marked cellular differentiation, the most proeminent phenomenon was B-cell stimulation. Indeed, in this model, the polyclonal activation was the most striking finding: a 1500 fold in the total splenic lg-S number was recorded at day 18. This association between polyclonal B-cell activation and ongoing parasitaemia has recently been reported also in human malaria (Banic et al., 1991). In that case polyclonal stimulation decreased during treatment and disappeared 5 to 15 days after the start of chemotherapy.

In the present study, no concomitance was observed between the maximum of total $\mathrm{Ig}$ (yet increasing at day 18), the peak of antiSRBC (day 4) and that of anti-TNP-SRBC (day 9) PFC responses. These discrepancies, also observed by other authors with these or other antigens (Freeman \& Parish, 1978; Rosenberg, 1978), suggest that the B-cell activation taking place during malaria infection may be not a direct consequence of a generalized, "non-specific", triggering of all B-cell clones but rather an antigen dependent process as previously proposed (Daniel-Ribeiro et al., 1983). A similar kinetics of specific response, but with a later peak was observed by Mori et al. (1987), who studied the model of mice infected with a $P$. berghei sporozoite. These authors claimed that the observation of heterologous (as well as autologous) antibody production before the appearance of blood forms could be due to mitogenic properties of sporozoites (Ojo-Amaize et al., 1984). In the present work, however, specific antibody response was observed in mice infected with blood forms of Plasmodium even before any increase in the total number of Ig-S cells was recorded, clearly showing that the heterologous antibody forma- tion is not a consequence of the polyclonal activating properties of Plasmodium.

Another fact that seems to support the hypothesis that Ag-specific PFCs are not activated by a generalized polyclonal activation is the observation that extracts, thought to contain parasite-derived substances, induce a marked ( 5 to 30 fold) increase in the number of background PFC specific to SRBC (but not to TNP) in spite of their limited effects ( 2.5 to 3.0 fold increase) on the total Ig-C and Ig-S numbers. Similar findings were reported by Rosenberg (1978) showing that injection of non-proliferating irradiated parasites was followed by marked increase in the number of anti-SRBC and of anti-brMRBC PFC, without significantly altering the total Ig PFC values. Other facts seem to corroborate this hypothesis: i) Ag-specific T-helper cells generated by immunization with some antigens can induce an increase in the total number of Ig-S (Rosenberg \& Chiller, 1979), therefore, similar mechanisms could operate in the induction of a discrete, although significant, increase in the number of $\mathrm{Ig}-\mathrm{S}$ and Ig-C triggered by injection of our parasite-derived extracts; ii) in the present and in previous reports (Freeman \& Parish, 1978; Rosenberg, 1978, 1981), the kinetics of $\mathrm{PFC}$ response against heterologous $\mathrm{RBC}$, induced both by malaria infection and parasite-derived substances, mimicked that the primary immune response elicited by injection of SRBC. Antigens cross-reacting with SRBC determinants could be present on the parasite itself or arise from modified autologous components. In this regard, it may be of interest to emphasize that cross-reaction between SRBC and brMRBC does exist (Pages \& Bussard, 1975).

The importance of antigen cross-reactions in the generation of polyclonal B-cell activation can also be exemplified by the model of T. cruzi infection (Minoprio et al., 1988). This study clearly shows that although a minor part of the activated B-lymphocytes in acute $T$. cruzi infection secrete antibodies that bind to parasites, a significant part of non-parasite specific antibodies is directed to autologous antigens, many of them being polyspecific. In the same way, the study of $\mathrm{V}_{\mathrm{H}}$-gene families in murine B-cell response to T. cruzi (Minoprio et al., 1989) suggest the large spectrum of polyclonal activation that can be observed during the course of a protozoan infection. 
In this study, hemolysates of $P$. yoelii infected RBC were found to exercise limited effects on the number of anti-TNP-SRBC PFC responses as compared to malaria infection. This could indicate that the anti-TNP response observed in infected animals is neither induced by antigens present on the parasite itself nor by autologous modified RBC antigens, but would rather appear as a result of stimulation of TNP-specific cells by cross-reactive host antigens released or expressed, later in the course of infection.

One alternative for the present hypothesis is that both antigen-specific and non-specific lymphocyte stimulation would depend on two activating signals as previously proposed (Watson et al., 1973; Daniel-Ribeiro et al., 1983): one delivered by Ig receptor after contact with antigen and a second resulting from (in the case of autoantigen) or being potentiated by (in the case of heteroantigen) the parasite-derived mitogens (Wyler et al., 1979; Ballet et al., 1981).

In such a model of PBA, one should have to postulate the existence of a cascade of generation of new antigens and one mechanism that could be evoked as a potential participant in this phenomenon is the idiotype-anti-idiotype network (Jerne, 1974). In this way, early in the course of infection, parasite or modified autoantigens cross-reacting with heterologous antigens (such as SRBC) would induce a transient specific immune response that would result in expression of idiotypes and secondarily in subsequent transient anti-idiotype responses. The generation of these successive (and cumulative in terms of Ig synthesis) immune responses would finish by giving rise to cross-reactivities between idiotypes and other heteroantigens (this would explain the late appearance of the anti-TNP-SRBC PFC response in the course of infection). Our preliminary results have demonstrated that cross-reactivities between idiotypes of antibodies directed to non plasmodial antigens, synthetic peptides corresponding to epitopes of sporozoite or hepatic stage plasmodial antigens and other heterologous antigens do exist (Daniel-Ribeiro, C., in press). All these considerations indicate that more work need to be done in these models before a definitive conclusion on the mechanisms of the malaria-associated Polyclonal B-cell activation can be drawn.

\section{ACKNOWLEDGEMENTS}

To Mrs Monique Bauzou for microscopic examination of blood films. Mrs Clemence Alfred-Morin for providing the supernatants of the in vitro culture of $P$. falciparum and Drs Jacques Couderc for technical advising. To Dr Lain Carlos Pontes de Carvalho for critically reviewing the manuscript.

\section{REFERENCES}

BALLET, J. J.; DRUIILHE, P.; QUERLEUX, M. A.; SCHIMITT, C. \& AGRAPART, M., 1981. Parasite derived mitogenic activity for human T-cell in Plasmodium falciparum continuous culture. Infect. Immun., 33: 758-762.

BANIC, D. M.; VIANA-MARTINS, F. S.; DE SOUZA, J. M.; PEIXOTO, T. C. \& DANIEL-RIBEIRO, C., 1991. Polyclonal B-lymphocyte stimulation in human malaria and its association with ongoing parasitaemia. Am. J. Trop. Med. Hyg., 44: 571-577.

COOPER, M. D.; LAWTON, A. R. \& BOCKMAN, D. E., 1971. A gammaglobulinaemia with B-lymphocytes specific defect of plasma-cell differentiation. The Lancet, ii: 791-791.

CORSINI, A. C. \& COSTA, M. G., 1981. Immunosuppression in mice infected with Trypanosoma cruzi (Chagas, 1909). I. Evidences for Polyclonal B-cell activation in experimental infections mimicked by an extract prepared from circulating trypomastigotes. Rev. Inst. Med. Trop. São Paulo, 23: 114-121.

CUNNINGHAM, A. J. \& SZENBERG, A., 1968. Further improvement in the plaque technique for detecting single antibody forming cell. Immunol., 14: 599-601.

DANIEL-RIBEIRO, C.; BANIC, D. M.; AHMED, I. A. \& GALVÃO-CASTRO, B., 1986. Polyclonal B-lymphocyte activation and sensitization of erythrocytes by IgG in human malaria: relevance to the development of anaemia in a holoendemic area in northwestern Brazil (Ariquernes-Rondonia). Mem. Inst. Oswaldo Cruz, Rio de Janeiro, Vol. 81, Suppl. II: 169-176.

DANIEL-RIBEIRO, C.; DESLANDES, D. C. \& FERREIRA-DA-CRUZ, M. F., 1991. Cross-reactions between idiotypes, Plasmodium falciparum derived peptides, dinitrophenyl and $\beta$ (2-6) polyfructosan. $J$. Clin. Lab. Immunol. (in press).

DANIEL-RIBEIRO, C.; DRLTLHE, P.; MONJOUR, L.; HOMBERG, J. C. \& GENTILINI, M., 1983. Specjficity of auto-antibodies in malaria and the role of polyclonal activation. Trans. $R$. Soc. Trop. Med. Hyg., 77: 185-188.

DRESSER, D. W., 1978. Assays for immunoglobulin secreting cells, p. 28.1-28.25. In Handbook of Experimental Immunology, Vol. 2 (Cellular Immunology) (3rd ed.), Blackwell Scientific Publications, Oxford.

DRUILHE, P.; JACQUIER, P.; LAMBERT, D. \& GENTILINI, M., 1980. Plasmodium falciparum in vitro culture improvement using umbilical cord serum and medium modifications. Trop. Med. Parasitol., 31: 409-413. 
FALANGA, P.; D'IMPERIO-LIMA, M. R.; COUTINHO, A. \& PEREIRA-DA-SILVA, L., 1987. Isotypic pattem of the polyclonal B-cell response during primary infection by Plasmodium chabaudi and in immune protected mice. Eur. J. Immunol., 17: 599. 603.

FAUCI, A. S. \& PRATT, K. R., 1976. Activation of human B lymphocytes. I. Direct plaque-forming cell assay for the measurement of polyclonal activation and antigenic stimulation of B. lymphocytes. J. Exp. Med., 114: 674-684.

FREEMAN, R. R. \& PARISH, C. R., 1978. Polyclonal $B$ cell activation during rodent malarial infections. Clin. Exp. Immunol., 32: 41-45.

GREENWOOD, B. M., 1974. Possible role of a B cell mitogen in hypergammaglobulinaemia in malaria and trypanosomiasis. The Lancet, i: 435-436.

GREENWOOD, B. M.; MULLER, A. S. \& VALKENBURG, H. A., 1971. Rheumatoid factor in Nigerian sera. Clin. Exp. Immunol., 8: 161-173.

GRONOWICZ, E.; COUTINHO, A. \& MELCHERS, F., 1976. A plaque assay for all secreting $\mathrm{Ig}$ of a given type or class. Eur. J. Immunol., 6: 588-590.

HOUBA, V.; PAGE-FAULK, W.\& MATOLA, G., 1974. Heterophylic antibodies in relation to malaria infection: population and experimental studies. Clin. Exp. Immunol., 18: 89-93.

JERNE, N. K., 1974. Towards a network theory of the immune system. Ann. Inst. Pasteur/Immunol., 125C: 373-389.

LANGHORNE, J.; KIM, K. J. \& ASOFSKY, R., 1985. Distribution of immunoglobulin isotypes in the nonspecific B-cell response induced by infection with Plasmodium chabaudi adami and Plasmodium yoelii. Cell. Immunol., 90: 251-257.

MINOPRIO, P.; ANDRADE, L.; LEMBEZAT, M.; OZAKI, L. S. \& COUTINHO, A., 1989. Indiscriminate representation of $\mathrm{V}^{\mathrm{H}}$-gene families in the murine B lymphocyte responses to Trypanosoma cruzi. J. Immunol., 142: 4017-4021.

MINOPRIO, P.; BURLEN, O.; PEREIRA, P.; GUILBERT, B.; ANDRADE, L.; HONTEBEYRIEJOSKOWICZ, M. \& COUTINHO, A., 1988. Most B cells in acute Trypasonoma cruzi infection lack parasite specificity. Scand. J. Immunol., 28: 553561.

MORI, M.; NATARAJAN, K.; BETSCHANT, B.; WEISS, N. \& FRANKLIN, R. M., 1987. Polyclonal
B-cell activation and autoantibody formation during the course of mosquito-transmitted Plasmodium berghei infection in mice. Trop. Med. Parasitol., 38: $157-162$.

OJO-AMAIZE, E. A.; VILCEK, J.; COCHRANE, A. \& NUSSENZWEIG, R. S., 1984. Plasmodium berghei sporozoites are mitogenic for murine $T$ cells, induce interferon and activate natural killer cells. $J$. Immunol., 133: 1005-1009.

PAGES, J. \& BUSSARD, A. E., 1975. Precommitment of normal mice peritoneal cells by erythrocytes antigens in relation to autoantibody production. Nature, 257: 316-317.

PLAYFAIR, J. H. L.; DE SOUZA, J. B. \& COTTRELL, B. J., 1977. Protection of mice against malaria by a killed vaccine: differences in effectiveness against $P$. yoelii and $P$. berghei. Immunol., 33: 507-515.

RITTENBERG, M. B. \& PRATT, K. L., 1969. Antitrinitrophenyl (TNP) plaque assay: primary response of $\mathrm{Balb} / \mathrm{c}$ mice to soluble and particulate immunogen. Proc. Soc. Exp. Biol. Med., 132: 575-581.

ROSENBERG, Y. J., 1978. Autoimmune and polyclonal $B$ cell responses during murine malaria. Nature, 274: 170-172.

ROSENBERG, Y. J., 1981. The ability of nonspecific $T$-cell stimulators to induce helper-cell dependent increases in either polyclonal or isotypes restricted Ig production. Cell Immunol., 61: 416-424.

ROSENBERG, Y. J. \& CHILLER, J. M., 1979. Ability of antigen-specific helper cell to effect a class-restricted increase in total Ig-secreting cells in spleen after immunization with the antigen. J. Exp. Med., 150: $517-530$.

WATSON, J.; TRENKNER, E. \& COHN, M., 1973. The use of bacterial lipopolysaccharides to show that two signals are required for the induction of antibody synthesis. $J$. Exp. Med., 138: 699-714.

WEINBAUM, F. I.; WEINTRAUB, J.; NKRUMAH, F. K.; EVANS, C. B.; TIGELAAR, R. E. \& ROSENBERG, Y. J., 1978. Immunity to Plasmodium berghei yoelii in mice. II. Specific and nonspecific cellular and humoral responses during the course of infection. J. Immunol., 121: 629-636.

WYLER, D. J.; HERROD, H. G. \& WEINBAUM, F. I., 1979. Response of sensitized and unsensitized human lymphocytes subpopulations to Plasmodium falciparum antigens. Infect. Immun., 24: 106110. 